\title{
Hybrid lesion in a child presenting with cough, fever and haemoptysis
}

\author{
Pierre Goussard (ㄷ), ${ }^{1}$ Savvas Andronikou, ${ }^{2}$ Lunga Mfingwana, ${ }^{1}$ Jacques Janson ${ }^{3}$
}

${ }^{1}$ Paediatrics and Child Health, Stellenbosch University Faculty of Medicine and Health Sciences, Cape Town, Western Cape, South Africa ${ }^{2}$ Department of Paediatric Radiology, Philadelphia University, Philadelphia, Pennsylvania, USA

${ }^{3}$ Cardiothoracic Surgery, Stellenbosch University Faculty of Medicine and Health Sciences, Cape Town, Western Cape, South Africa

\section{Correspondence to} Professor Pierre Goussard; pgouss@sun.ac.za

Accepted 14 September 2020

\section{DESCRIPTION}

A 10-year-old boy presented with minimal haemoptysis after 1 week of cough and fever. He had a similar presentation 3 years earlier; the diagnosis at that stage was right lower lobe pneumonia. He is HIV uninfected and has no known tuberculosis exposure. Investigations revealed a raised white cell count of $19.0 \times 10^{9} / \mathrm{L}$, raised C reactive protein 217 $\mathrm{mg} / \mathrm{L}$, normal clotting studies and the GeneXpert MTB/RIF was negative.

Chest radiograph (figure 1) demonstrated a dense opacity in the right lower lobe posterior segment but without any air bronchograms and sharply demarcated anterior/medial margins, not corresponding to an anatomic boundary. A comparative chest radiograph from 3 years previously (figure 1B) revealed a pre-existing density with an associated air-filled cystic component (the latter not visible on the current radiograph). A CT chest scan was performed to investigate for an underlying lesion and revealed a large subdiaphragmatic vessel arising from the descending aorta, coursing towards a soft tissue density vascularised mass, in the right lower lobe posterior segment, in keeping with a sequestration (figure 2). The presence of multiple associated cystic lesions (with air-fluid levels suggesting superinfection) was radiologically indicative of a hybrid lesion.

Surgery was delayed for 6 weeks while awaiting resolution of the pneumonia. A 4-week course of oral amoxicillin/clavulanate was completed prior to surgery.

A right-sided lateral thoracotomy was performed, confirming a large abnormal arterial vascular supply to the right lower lobe, prompting a right lower lobe lobectomy (video 1). There were adhesions

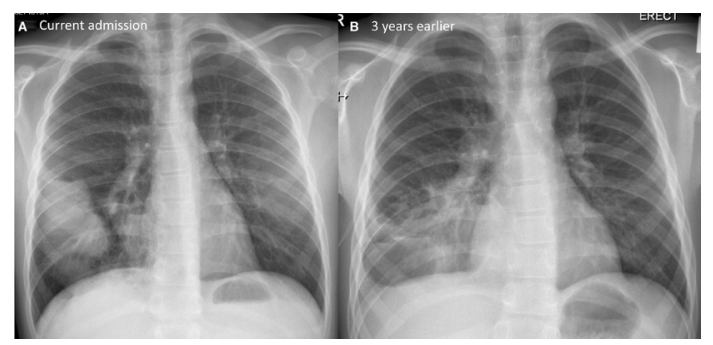

BM] Publishing Group Limited 2020. No commercial re-use. See rights and permissions. Published by BMJ.

To cite: Goussard $P_{\text {, }}$ Andronikou S, Mfingwana L, et al. BMJ Case Rep 2020:13:e238796 doi:10.1136/bcr-2020238796
Figure 1 (A) Current chest radiograph in a 10-year-old boy who presented of haemoptysis after 1 week of cough and fever demonstrates a right lower lobe posterior segment opacity without air-bronchograms and with sharp anterior/medial borders, not corresponding to an anatomic boundary. (B) Comparison radiograph from 3 years previously demonstrates the opacity in the right lower lobe with an associated air-filled cystic component.

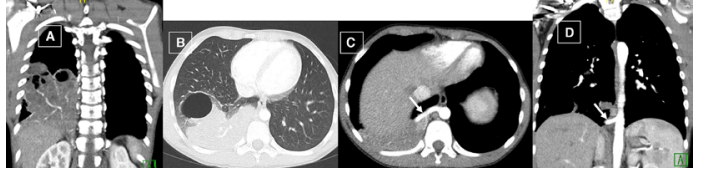

Figure 2 Coronal and axial images on soft tissue and lung window of the chest after administration of intravenous contrast reveals the vascularised soft tissue mass in the right lower lobe $(A)$ containing air-filled cysts $(A, B)$ as well as an abnormal large vessel arising from the supratentorial descending aorta feeding the mass (C, D arrows), in keeping with a hybrid sequestrationcongenital cystic adenomatoid malformation lesion.

present, probably due to previous lower respiratory tract infection. The lesion was invested within the same visceral pleura as the right lower lobe, consistent with an intralobar sequestration. Histology demonstrated innumerable cysts of varying diameters, lined by respiratory-type epithelium, with walls containing fibrous tissue and scanty smooth muscle fibres, but no cartilage. The cysts merge with relatively normal appearing alveolar tissue. The histological features confirmed that this was indeed a congenital pulmonary airway malformation (CPAM), type 2. With the CT demonstrating a blood supply direct from the systemic circulation, the diagnosis was finalised as a hybrid type 2 CPAM with pulmonary sequestration.

The boy made a complete recovery and the right upper and middle lobe expanded to fill the chest cavity. His duration of hospital stay was 4 days. Follow-up chest radiograph, 2 months later, showed almost complete resolution.

Type 2 CPAM typically manifests with cysts, usually small, ranging from a few millimetres to $2 \mathrm{~cm}$ in diameter. Microscopically, cysts have a bronchiolar-like structure and epithelial lining. Cysts can replace the normal lung parenchyma or can be scattered with relatively normal-appearing

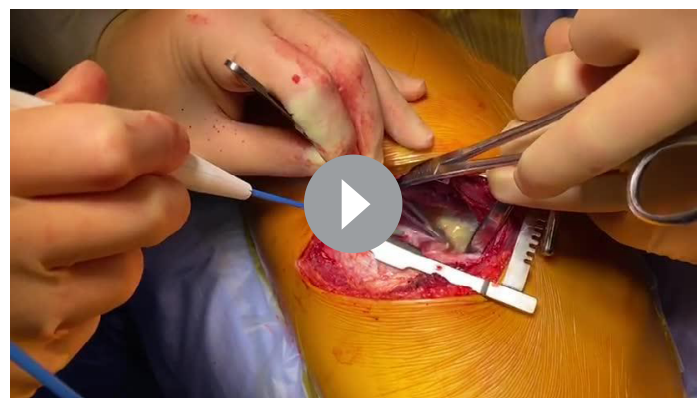

Video 1 Intraoperative video demonstrating the large feeding vessel to the hybrid lesion. 
intervening alveoli. Cartilage is normally absent and mucigenic epithelium is not seen. ${ }^{1}$ Intralobar sequestration is defined as occurring in a lobe, or part of a lobe, lying within the visceral pleura, isolated from the tracheobronchial tree and associated with an anomalous blood supply. ${ }^{2}$ Hybrid lesions are rare congenital lesions with a combination of a cystic adenomatoid malformation and an anomalous systemic blood supply. ${ }^{23}$

Prenatal diagnosis of hybrid lesions may be difficult. Demonstrating a systemic arterial supply from the aorta to the lesion by colour-flow doppler ultrasound may be diagnostic of a hybrid lesion if both the cystic lesions and the systemic arterial supply are seen. ${ }^{4}$ Hybrid lesions must be included in the differential diagnosis of recurrent pneumonia, especially if cystic lesions

\section{Learning points}

- Undiagnosed congenital lung lesions must be considered in older children presenting with recurrent pneumonia.

- Cystic changes suggestive of congenital pulmonary airway malformation (CPAM) may be visible on follow-up chest radiograph after the acute changes have resolved.

- Hybrid CPAM lesions may be more common than previously thought and have risk of haemoptysis; prophylactic surgery is often recommended if this lesion is identified incidentally (either in utero or early childhood), regardless of symptoms, to avoid the fairly predictable complication of pneumonia. are seen on chest radiograph, and if the patient presents with haemoptysis. The risk for haemoptysis may be significant if there is bleeding from the systemic circulation into the airways, which was the likely scenario in our patient.

Contributors PG wrote the case presentation and prepared images to be included with the manuscript. SA performed a literature review and wrote the discussion section. JJ and LM assisted with literature review and discussion and also reviewed the paper. PG reviewed the paper and made several modifications to the discussion section.

Funding The authors have not declared a specific grant for this research from any funding agency in the public, commercial or not-for-profit sectors.

Competing interests None declared.

Patient consent for publication Parental/guardian consent obtained.

Provenance and peer review Not commissioned; externally peer reviewed.

ORCID iD

Pierre Goussard http://orcid.org/0000-0003-1146-1307

\section{REFERENCES}

1 Fowler DJ, Gould SJ. The pathology of congenital lung lesions. Semin Pediatr Surg 2015:24:176-82.

2 Seear M, Townsend J, Hoepker A, et al. A review of congenital lung malformations with a simplified classification system for clinical and research use. Pediatr Surg Int 2017;33:657-64.

3 Cass DL, Crombleholme TM, Howell LJ, et al. Cystic lung lesions with systemic arterial blood supply: a hybrid of congenital cystic adenomatoid malformation and bronchopulmonary sequestration. J Pediatr Surg 1997;32:986-90.

4 Achiron R, Hegesh J, Yagel S. Fetal lung lesions: a spectrum of disease. New classification based on pathogenesis, two-dimensional and color Doppler ultrasound. Ultrasound Obstet Gynecol 2004;24:107-14.

Copyright 2020 BMJ Publishing Group. All rights reserved. For permission to reuse any of this content visit

https://www.bmj.com/company/products-services/rights-and-licensing/permissions/

BMJ Case Report Fellows may re-use this article for personal use and teaching without any further permission.

Become a Fellow of BMJ Case Reports today and you can:

- Submit as many cases as you like

- Enjoy fast sympathetic peer review and rapid publication of accepted articles

- Access all the published articles

- Re-use any of the published material for personal use and teaching without further permission

Customer Service

If you have any further queries about your subscription, please contact our customer services team on +44 (0) 2071111105 or via email at support@bmj.com.

Visit casereports.bmj.com for more articles like this and to become a Fellow 